\title{
Differential regulation of mouse pancreatic islet insulin secretion and Smad proteins by activin ligands
}

\author{
Haiya Wu • Karima Mezghenna • Patricia Marmol • \\ Tingqing Guo • Annalena Moliner • Shao-Nian Yang • \\ Per-Olof Berggren • Carlos F. Ibáñez
}

Received: 14 June 2013 / Accepted: 23 September 2013 / Published online: 17 October 2013

(C) Springer-Verlag Berlin Heidelberg 2013

\begin{abstract}
Aims/hypothesis Glucose-stimulated insulin secretion (GSIS) from pancreatic beta cells is regulated by paracrine factors, the identity and mechanisms of action of which are incompletely understood. Activins are expressed in pancreatic islets and have been implicated in the regulation of GSIS. Activins A and B signal through a common set of intracellular components, but it is unclear whether they display similar or distinct functions in glucose homeostasis.

Methods We examined glucose homeostatic responses in mice lacking activin $\mathrm{B}$ and in pancreatic islets derived from these mutants. We compared the ability of activins A and B to regulate downstream signalling, ATP production and GSIS in islets and beta cells.

Results Mice lacking activin B displayed elevated serum insulin levels and GSIS. Injection of a soluble activin B antagonist phenocopied these changes in wild-type mice. Isolated pancreatic islets from mutant mice showed enhanced GSIS, which could be rescued by exogenous activin B. Activin B negatively regulated GSIS and ATP production in wild-type
\end{abstract}

Electronic supplementary material The online version of this article (doi:10.1007/s00125-013-3079-6) contains peer-reviewed but unedited supplementary material, which is available to authorised users.

H. Wu $\cdot$ K. Mezghenna $\cdot$ P. Marmol $\cdot$ T. Guo $\cdot$ A. Moliner $\cdot$

C. F. Ibáñez $(\bowtie)$

Department of Neuroscience, Rolf Luft Research Center for Diabetes and Endocrinology, Karolinska Institutet, Berzelius vag 35, B3 Box 285, SE-171 77 Stockholm, Sweden

e-mail: carlos.ibanez@ki.se

S.-N. Yang $\cdot$ P.-O. Berggren

Rolf Luft Research Center for Diabetes and Endocrinology,

Karolinska Institutet, Stockholm, Sweden

C. F. Ibáñez

Life Sciences Institute, Department of Physiology, National

University of Singapore, Singapore, Republic of Singapore islets, while activin A displayed the opposite effects. The downstream mediator Smad3 responded preferentially to activin B in pancreatic islets and beta cells, while Smad2 showed a preference for activin $\mathrm{A}$, indicating distinct signalling effects of the two activins. In line with this, overexpression of Smad3, but not Smad2, decreased GSIS in pancreatic islets.

Conclusions/interpretation These results reveal a tug-of-war between activin ligands in the regulation of insulin secretion by beta cells, and suggest that manipulation of activin signalling could be a useful strategy for the control of glucose homeostasis in diabetes and metabolic disease.

Keywords ALK7 · ATP · GSIS · Insulin secretion · Islet . Mitochondria $\cdot$ Smad $\cdot$ TGF- $\beta$

\section{Abbreviation \\ GSIS Glucose-stimulated insulin secretion}

\section{Introduction}

The TGF- $\beta$ superfamily comprises a large group of structurally related ligands, including TGF- $\beta$ s, growth and differentiation factors, bone morphogenetic proteins and activins. These factors signal via complexes of type I and type II receptor serine-threonine kinases, each binding to different classes of TGF- $\beta$ ligands $[1,2]$. The best known signalling pathway downstream of TGF- $\beta$ superfamily receptors involves phosphorylation and nuclear translocation of Smad proteins, which in turn regulate gene transcription through interactions with transcription factors in a cell-type-specific manner [1, 2]. Cytoplasmic functions of Smad proteins have also been described, but their physiological significance is still unclear [3]. TGF- $\beta$ superfamily proteins are best known for 
their roles in cell differentiation, organogenesis and tissue homeostasis. In comparison, much less is known about their roles as acute mediators of adult metabolic functions.

Paracrine factors are known to regulate glucose-stimulated insulin secretion (GSIS) from pancreatic beta cells, but their identity and mechanisms of action are not well understood. TGF- $\beta$ s 1 and 2 are expressed in islets and have been shown to acutely enhance GSIS [4-6]. Activins A and B are also expressed in islet cells, suggesting autocrine and/or paracrine roles in islet cell function and glucose homeostasis [7-11]. Immunohistochemical studies have localised activin A predominantly to alpha cells, while activin B was shown to be expressed by both alpha and beta cells [4]. Earlier work showed that exogenous activin A can increase the cytoplasmic free $\mathrm{Ca}^{2+}$ concentration and stimulate insulin secretion in human and rat pancreatic islets, even at low levels of ambient glucose [12-14]. Those results have been challenged by more recent studies indicating that in mouse islets, activin A either has no effect [4] or may in fact decrease GSIS [15, 16]. It has been assumed in several of these studies that activin A and B signal in a similar fashion and thus have similar functions in pancreatic islets. However, the role of activin B in the paracrine control of insulin secretion has not been thoroughly investigated.

We have previously shown that the type I receptor ALK7 is a negative regulator of pancreatic beta cell function [17]. ALK7 is expressed by all major islet cell types and, together with the type II receptor ACTRIIB, can signal in response to several members of the TGF- $\beta$ superfamily, including activin $\mathrm{B}$, but not activin A [18-22]. On the other hand, both activin proteins are able to signal through the related receptor ALK4. Mutant mice lacking ALK7 exhibit fasting hyperinsulinaemia, and pancreatic islets derived from Alk7 (also known as Acvrlc) mutants show enhanced GSIS [17]. Similar to Alk7 knockouts, mutant mice lacking activin B display high serum insulin levels as adults [17], suggesting that activin B might function as an endogenous suppressor of insulin secretion in pancreatic islets.

In the present study, we examined glucose homeostatic responses in mice lacking activin $\mathrm{B}$ and in pancreatic islets derived from these mutants. We also compared the ability of the two activin proteins to regulate downstream signalling and GSIS in islets and beta cells. The results demonstrated that activins can elicit distinct acute signalling responses and differential regulation of insulin release in pancreatic islets, revealing a novel layer of paracrine control of insulin secretion based on antagonistic activin signalling.

\section{Methods}

Animals The generation of $\operatorname{Inh} \beta B^{-/}$(also known as $\operatorname{Inh} b b^{-/}$) mice has previously been described [23]. They were obtained from the Jackson Laboratory (Bar Harbor, Maine, USA). All experiments in the present study were performed on mice back-crossed for several generations to a $\mathrm{C} 57 \mathrm{Bl} / 6$ background. Male mice were used for all the studies. Animal protocols were approved by Stockholm's Norra djurförsöksetiska nämnd in accordance with ethical guidelines of the Karolinska Institutet.

Insulin measurements and glucose tolerance test A glucose tolerance test was performed as described [17] after overnight fasting. Serum insulin was measured with an ultrasensitive mouse insulin ELISA kit (Mercodia, Stockholm, Sweden) from tail blood at the indicated time points before and after i.p. injection of $2 \mathrm{~g} / \mathrm{kg}$ (body weight) glucose. RAP-435 was injected i.p. at $10 \mathrm{mg} / \mathrm{kg}$ twice a week for 4 weeks, followed by examination of fasting glucose and insulin levels and a glucose tolerance test.

Quantification of islet mass Pancreases were removed from three different mice for each genotype ( 2 months old and weight-matched) and immediately fixed in $4 \%$ paraformaldehyde overnight at $4^{\circ} \mathrm{C}$. They were then immersed in $30 \%$ sucrose overnight at $4^{\circ} \mathrm{C}$ and cryopreserved in optimum cutting temperature compound (Histolab, Stockholm, Sweden) at $-80^{\circ} \mathrm{C}$. Sections $(10 \mu \mathrm{m})$ were cut on a cryostat and stained with haematoxylin and eosin. Three sections per animal, $140 \mu \mathrm{m}$ apart, were analysed. For each section, images were acquired with an Axiovert 200 inverted microscope (Carl Zeiss, Stockholm, Sweden) using $\times 1.25$ and $\times 5$ objectives to determine, respectively, pancreas sections and islet areas. An islet was defined as a cluster of at least four cells. Each image was calibrated to calculate the area in $\mu \mathrm{m}^{2}$ using ImageJ software (National Institutes of Health, Bethesda, MD, USA). The total islet mass was calculated as the total area of islets expressed as a percentage of the total pancreas area.

Islet insulin release, perfusion and ATP production For each experiment, pancreatic islets were isolated from three or four pancreases by collagenase dispersion and pooled [24]. Isolated islets were left to recover overnight at $37^{\circ} \mathrm{C}(5 \%$ $\mathrm{CO}_{2}$ ) in RPMI medium containing $11 \mathrm{mmol} / \mathrm{l}$ glucose and supplemented with $100 \mu \mathrm{g} / \mathrm{ml}$ streptomycin, $100 \mu \mathrm{g} / \mathrm{ml}$ penicillin, $2 \mathrm{mmol} / \mathrm{l}$ glutamine and 10\% FBS. After overnight incubation, groups each containing ten size-matched islets were glucose-starved by incubation at $37^{\circ} \mathrm{C}$ for $45 \mathrm{~min}$ in HEPES buffer ( $\mathrm{pH}$ 7.4) containing (in mmol/l) $125 \mathrm{Nalco}, 5.9$ $\mathrm{KCl}, 1.2 \mathrm{MgCl}_{2}$ and $1.28 \mathrm{CaCl}_{2}$, supplemented with $3 \mathrm{mmol} / \mathrm{l}$ glucose and $1 \mathrm{mg} / \mathrm{ml} \mathrm{BSA}$.

For stimulation, islets were switched to a solution of the same buffer containing either $3 \mathrm{mmol} / \mathrm{l}$ (control) or $11 \mathrm{mmol} / \mathrm{l}$ (stimulated) glucose for $60 \mathrm{~min}$ at $37^{\circ} \mathrm{C}$, with or without activin treatments. Although some studies have used higher glucose concentrations to stimulate islets (e.g. $16 \mathrm{mmol} / \mathrm{l}$ or higher), we chose an intermediate concentration to increase 
the dynamic range and allow for potential positive as well as negative effects of activins on GSIS. The supernatant fraction was assayed for secreted insulin by ELISA and the islets were collected for measurements of DNA content for normalisation. Independent experiments showed no significant differences in insulin content between wild-type and knockout islets or after treatment with activins. Where indicated, activin A or activin B (R\&D Systems, Stockholm, Sweden) was added to the final incubation medium at $30-100 \mathrm{ng} / \mathrm{ml}$, a concentration range used in previous islet studies. The inhibitor SB-431542 (Sigma, Stockholm, Sweden) [25] was used at a final concentration of $10 \mu \mathrm{mol} / 1$. ATP was measured in lysates using the ATPlite 1step Luminescence Assay System (Perkin-Elmer, Stockholm, Sweden). ATP values were normalised to total islet protein content. For perfusion experiments, groups of 80 isolated islets were transferred to $0.27 \mathrm{ml}$ columns containing Bio-Gel P4 polyacrylamide beads (Bio-Rad, Stockholm, Sweden) and perfused at a flow rate of $0.2 \mathrm{ml} / \mathrm{min}$ at $37^{\circ} \mathrm{C}$ as previously described [26]. HEPES-based buffer (as above) was used as a perfusion solution supplemented with $3 \mathrm{mmol} / \mathrm{l}$ glucose, $11 \mathrm{mmol} / 1$ glucose or $25 \mathrm{mmol} / \mathrm{KCl}$, as indicated. Effluent samples were collected every $1 \mathrm{~min}$ for the duration of the experiments and assayed for insulin concentration by ELISA. Islet DNA was isolated from each perfusion column and quantified for normalisation.

Real-time PCR Total RNA from islets was extracted using the RNeasy Mini Kit (Qiagen, Stockholm, Sweden). First-strand cDNA was obtained from $500 \mathrm{ng}$ total RNA using SuperScript II RNase $\mathrm{H}^{-}$Reverse Transcriptase (Invitrogen, Stockholm, Sweden). Real-time quantitative PCR was carried out to assess the expression of $\operatorname{Inh} \beta A$ and $\operatorname{Inh} \beta B$ mRNAs and $18 \mathrm{~S}$ rRNA (as an endogenous normalisation control) using the specific primers (see electronic supplementary material [ESM] Table 1). PCR was performed with SYBR Green PCR Master Mix (Applied Biosystems, Stockholm, Sweden) on a StepOnePlus real-time PCR system (Applied Biosystems). For a quantitative comparison of $\operatorname{Inh} \beta A$ and Inh $\beta B$ mRNA levels, each quantitative PCR experiment was run alongside a standard curve for each target amplicon created by serial dilutions of a known quantity of $\operatorname{Inh} \beta A$ and $\operatorname{Inh} \beta B$ cDNAs derived from islet RNA and subsequently purified by gel electrophoresis and quantified. $\operatorname{Inh} \beta A$ and Inh $\beta B$ mRNA levels were normalised to that of $18 \mathrm{~S}$ rRNA.

Electron microscopy Isolated islets were fixed using 2.5\% paraformaldehyde (wt/vol.) and $0.1 \%$ glutaraldehyde (vol./ vol.). Ultrathin sections of $60 \mathrm{~nm}$ were stained with $2 \%$ uranyl acetate and visualised with transmission electron microscopy. Three male mice from each genotype were analysed. For each mouse, three sections were chosen and seven pictures showing one beta cell were randomly taken from each section. For each pancreas, beta cells were analysed to determine the mitochondrial volume density (volume of mitochondria per unit of beta cell volume).

Adenoviruses Recombinant adenoviruses for expression of $\beta$-galactosidase, Smad 2 and Smad3 were provided by P. ten Dijke (Leiden University Medical Center, Leiden, The Netherlands) and have been described previously [27, 28]. Viral particles were produced and amplified in cultures of HEK293 cells (ATCC, Manassas, VA, USA), as previously described [27].

Western blotting Islets were dissected as above and cultured overnight in RPMI-based medium as pools of 80-100 islets per $3.5 \mathrm{~cm}$ culture dish. Islets were serum-starved $2 \mathrm{~h}$ prior to ligand stimulation. They were then treated with activins at $100 \mathrm{ng} / \mathrm{ml}$ for $1 \mathrm{~h}$ in the same RPMI-based medium. MEPI and INS- 1 cells were cultured as previously described [29, 30]. Islets and cell monolayers were lysed in lysis buffer (50 mmol/1 Tris-HCl, 0.15 mol/1 NaCl, 1\% Triton-X100, pH 7.4) supplemented with protease inhibitors ( $1 \mathrm{mmol} / \mathrm{l} \mathrm{PMSF}$ and $1 \mu \mathrm{g} / \mathrm{ml}$ aprotinin) and phosphatase inhibitors (NaPPi, phosphoglycerol and $\mathrm{NaO}_{4} \mathrm{Va}$ ). Total protein was quantified by the BCA method. Each batch of $80-100$ islets yielded approximately $50 \mu \mathrm{g}$ protein. In each case, $20 \mu \mathrm{g}$ protein was used for SDS/PAGE followed by immunoblotting. Membranes were probed with antibodies against total- and phospho-Smad2 (Cell Signaling, Stockholm, Sweden), totaland phospho-Smad3 (Epitomics, Stockholm, Sweden) or beta actin (Cell Signaling). Proteins were visualised using the ECL western blotting kit (Thermo Scientific, Stockholm, Sweden). Blots were imaged in an LAS 4000 unit using ImageQuant software (GE Healthcare, Stockholm, Sweden).

Data analysis The Student's $t$ test and ANOVA were used for statistical analyses.

\section{Results}

Mice lacking activin B $\left(\operatorname{Inh} \beta B^{-/}\right)$showed elevated serum insulin levels from early stages of postnatal development (Fig. 1a). This was accompanied by hypoglycaemia (Fig. 1b), suggesting normal insulin sensitivity at this age. Young adult (i.e. 2-month-old) $\operatorname{Inh} \beta B^{-/}$mice continued to display elevated fasting insulin levels compared with wildtype controls (Fig. 2a, $0 \mathrm{~min}$ ), but fasting glycaemia was normalised (Fig. 2b, $0 \mathrm{~min}$ ), indicating the development of insulin resistance in the mutants. At 2 months of age, there were no weight differences between wild-type and mutant mice, and the pancreatic islet mass of the mutants was indistinguishable from that of wild-type littermates (data not shown). After injection of glucose, $\operatorname{Inh} \beta B^{-/-}$mice displayed 

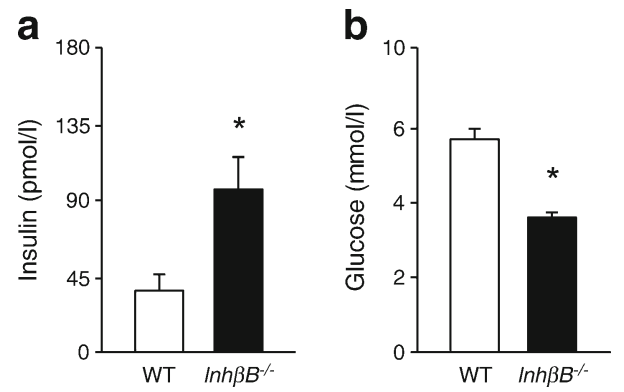

Fig. 1 Serum insulin (a) and glucose (b) levels in postnatal day 2 wildtype (WT) and $\operatorname{Inh} \beta B^{-/-}$mice. Data are means $\pm \mathrm{SD}\left(n=5\right.$ mice). ${ }^{*} p<0.05$

a much greater increase in serum insulin compared with wildtype mice (Fig. 2a). Glucose levels were also higher in mutant mice than in wild-type mice following glucose injection (Fig. 2b), indicating that, by 2 months of age, the mutants had begun to develop glucose intolerance. These results parallel the responses previously observed in mice lacking the ALK7 receptor, one of the two type I receptors for activin B, which show hyperinsulinaemia from early stages but develop insulin resistance and glucose intolerance over time [17].

RAP-435 is a recombinant fusion protein derived from an optimised human activin receptor IIB extracellular domain (ACTRIIB) fused to a human IgG1 Fc domain [31]. RAP435 can block ACTRIIB signalling and shows higher affinity for activin B compared with other TGF- $\beta$ superfamily ligands [31]. In order to assess whether endogenous activin $\mathrm{B}$ can exert homeostatic functions in the regulation of glucose and insulin levels in naive animals, we treated adult wild-type
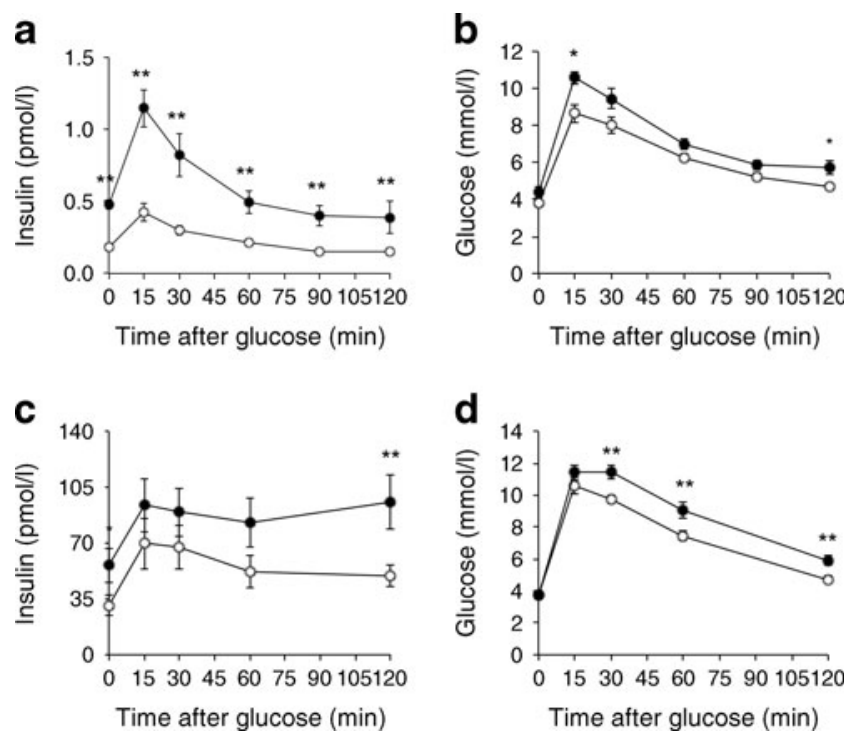

Fig. 2 Serum insulin (a) and glucose (b) levels after glucose injection in 2-month-old wild-type (open circles) and $\operatorname{Inh} \beta B^{-/-}$(solid circles) mice. Data are means $\pm \mathrm{SD}(n=5$ mice). Serum insulin (c) and glucose (d) levels after glucose injection in 2-month-old wild-type mice treated with RAP-435 (solid circles) or vehicle (PBS, open circles). Data are means \pm $\mathrm{SD}(n=14$ mice $) . * p<0.05, * * p<0.01$ mice with RAP-435 for 4 weeks and examined fasting insulin and glucose levels, as well as glucose tolerance. Treatment with RAP-435 resulted in higher fasting insulin levels and enhanced GSIS in wild-type mice (Fig. 2c). In addition, animals treated with RAP-435 showed partial glucose intolerance similar to that displayed by $\operatorname{Inh} \beta B^{-/-}$mice (Fig. 2d). Treatment with RAP-435 did not have any significant effect on body weight (data not shown). Together, these results indicate a role for activin $\mathrm{B}$ as an endogenous regulator of adult glucose and insulin responses.

GSIS was investigated in perfusion experiments with islets isolated from wild-type and $\operatorname{Inh} \beta B^{-/-}$mice. Mutant islets showed enhanced insulin secretion compared with wild-type islets, particularly during the second phase (24-42 $\mathrm{min}$ ) of continuous glucose stimulation (Fig. 3). Wild-type and mutant islets did not differ in their response to $\mathrm{KCl}$ (Fig. 3), indicating that the abnormal insulin secretion by knockout islets is a result of defects upstream of beta cell depolarisation.

Mutant islets also showed enhanced GSIS in batch incubation experiments (Fig. 4a). Importantly, the addition of activin $B$ during glucose stimulation rescued the abnormal insulin release of $\operatorname{Inh} \beta B^{-/-}$islets back to near wild-type levels
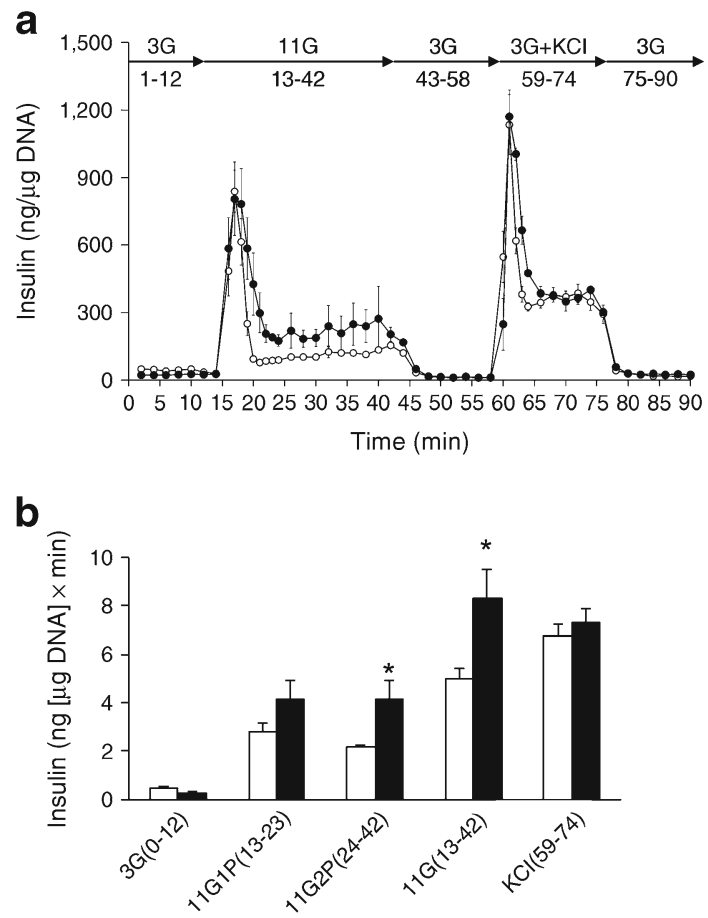

Fig. 3 (a) Insulin secretion profiles from perfusion experiments with wild-type (open circles) and $\operatorname{Inh} \beta B^{-/-}$(solid circles) islets. Treatments and their corresponding fraction numbers are summarised at the top. Data are presented as ng of insulin in perfusion eluate normalised to islet DNA content (means $\pm \mathrm{SD} ; n=5$ islet samples derived from pooled pancreases). (b) Histogram showing AUC calculations of perfusion experiments. Wild-type, open bars; $\operatorname{Inh} \beta B^{--}$, solid bars. Results are presented as ng insulin per min normalised to islet DNA content (means $\pm \mathrm{SD} ; n=5$ islet samples). $3 \mathrm{G}, 3 \mathrm{mmol} / 1$ glucose; $11 \mathrm{G}, 11 \mathrm{mmol} / \mathrm{l}$ glucose. ${ }^{*} p<0.05$ 

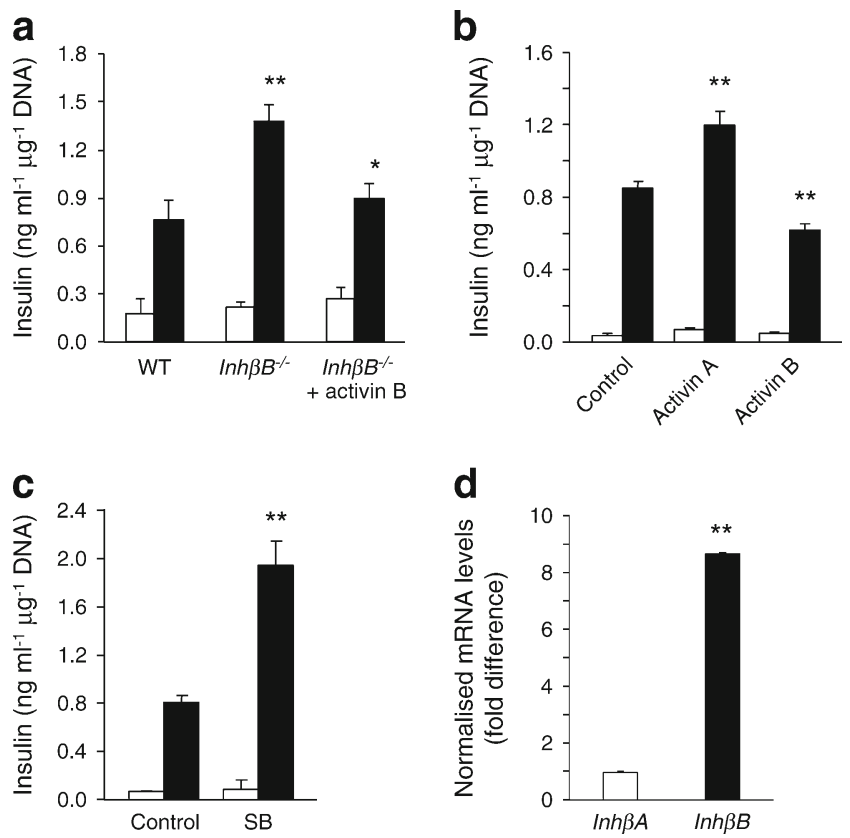

Fig. 4 GSIS in batch incubation experiments with (a) wild-type (WT) and $\operatorname{Inh} \beta B^{-/-}$islets, (b) WT islets treated with activin A, activin B or control and (c) WT islets treated with SB-431542 inhibitor (SB). Open bars, $3 \mathrm{mmol} / \mathrm{l}$ glucose; solid bars, $11 \mathrm{mmol} / \mathrm{l}$ glucose. Data are presented as $\mathrm{ng} / \mathrm{ml}$ of insulin normalised to islet DNA content (means $\pm \mathrm{SD} ; n=5$ islet samples). (d) Expression of $\operatorname{Inh} \beta A$ and $\operatorname{Inh} \beta B$ mRNAs encoding specific activin $A$ and $B$ peptide chains, respectively, in islets from young adult mice. The histogram shows results from real-time PCR experiments calibrated with normalised, activin-specific template standards to allow direct comparison of expression levels of the two amplicons. The level of $\operatorname{Inh} \beta A$ mRNA was set to 1 and the histogram is thus expressed as fold difference relative to Inh $\beta A$ mRNA levels. Data are means $\pm \mathrm{SD}$ of three independent determinations. ${ }^{*} p<0.05,{ }^{* *} p<0.01$

(Fig. 4a), supporting the idea that activin B plays a homeostatic role in the regulation of GSIS. The effects of activin B on $\operatorname{Inh} \beta B^{-/-}$islets prompted us to compare the acute actions of activin A and activin B on GSIS in islets isolated from 2month-old wild-type mice. The addition of activin A during glucose stimulation significantly enhanced insulin secretion compared with control (Fig. 4b). In contrast, activin B reduced GSIS under the same conditions (Fig. 4b). We also tested the effects of SB-431542, a small-molecule inhibitor of ALK4, ALK5 and ALK7 receptors that is widely used as a selective blocker of activin and TGF- $\beta$ signalling [25]. Interestingly, the addition of SB-431542 at the onset of glucose stimulation increased insulin secretion from wild-type islets by more than twofold, phenocopying deletion of the $\operatorname{Inh} \beta B$ gene (Fig. 4c), indicating that acute inhibition of activin/TGF- $\beta$ signalling enhances GSIS in wild-type islets. Because activin B is the only activin/TGF- $\beta$ ligand known to suppress GSIS, the effects of SB-431542 suggested that activin B could be the main endogenous activin produced in islets. To determine the relative endogenous levels of expression of the two activins, we compared the levels of $\operatorname{Inh} \beta A$ and $\operatorname{Inh} \beta B$ mRNAs encoding specific activin A and B peptide chains, respectively, using a real-time PCR protocol calibrated with normalised activinspecific template standards. Interestingly, $\operatorname{Inh} \beta B$ mRNA was expressed at ninefold higher levels than $\operatorname{Inh} \beta A$ in wild-type islets of adult mice (Fig. 4d), indicating that activin B is the predominant activin endogenously produced in mouse pancreatic islets.

In line with the inhibitory effect of activin B on GSIS, islets from $\operatorname{Inh} \beta B^{-/-}$mice showed increased ATP production in response to glucose compared with wild-type islets (Fig. 5a). This could in part be due to increased numbers of mitochondria (about 30\%) in beta cells from $\operatorname{Inh} \beta B^{-/-}$pancreases compared with wild-type controls, as assessed by electron microscopy (Fig. 5b). We also investigated acute effects of activins on ATP production by pancreatic islets. In agreement with their effects on insulin secretion, ATP production in glucose-stimulated wild-type islets was enhanced by activin A but suppressed by activin B (Fig. 5c), indicating antagonistic effects of activins on glucose-stimulated ATP production by pancreatic islets. Together, these results reveal antagonistic effects of activin A and B proteins in GSIS and ATP production by pancreatic islets.
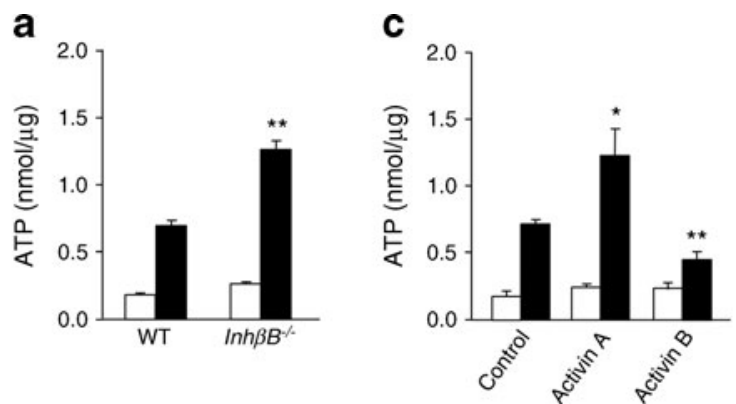

b
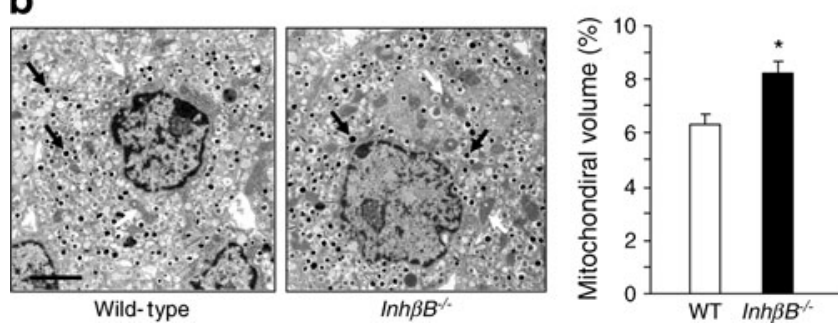

Fig. 5 (a) Glucose-stimulated ATP production in wild-type (WT) and $\operatorname{Inh} \beta B^{-/-}$islets. Open bars, $3 \mathrm{mmol} / \mathrm{l}$ glucose; solid bars, $11 \mathrm{mmol} / \mathrm{l}$ glucose. Data are presented as nmol ATP normalised to $\mu \mathrm{g}$ protein (means $\pm \mathrm{SD} ; n=5$ islet samples). (b) Electron microscopy analysis of mitochondrial volume in beta cells of pancreatic islets derived from wild-type and $\operatorname{Inh} \beta B^{-/}$mice. Representative micrographs are shown on the left. White arrows indicate mitochondria. The histogram depicts percentage mitochondrial volume relative to cytoplasmic volume for wild-type and mutant beta cells (means $\pm \mathrm{SD} ; n=3$ mice). Only beta cells, identified in micrographs by the presence of characteristic electron-dense insulin granules (black arrows), were used for this analysis. Scale bar, $2 \mu \mathrm{m}$. (c) Glucose-stimulated ATP production in wild-type islets treated with activin A, activin B or control. Open bars, $3 \mathrm{mmol} / \mathrm{l}$ glucose; solid bars, $11 \mathrm{mmol} / \mathrm{l}$ glucose. Data are presented as nmol ATP normalised to $\mu \mathrm{g}$ protein (means $\pm \mathrm{SD} ; n=5$ islet samples). ${ }^{*} p<0.05 ;{ }^{* *} p<0.01$ 
The differential activities of activin A and B on GSIS and ATP production are striking, given that these proteins have by and large been regarded as qualitatively equivalent with regards to their signalling and function [32]. We therefore sought to correlate their functional differences with intracellular signalling events in pancreatic islets and beta cells. Activin stimulation of responsive cells is known to result in receptor-mediated phosphorylation of Smad2 and Smad3, the main intracellular mediators of activin and TGF- $\beta$ signalling. All activins and TGF- $\beta$ ligands are thought to activate the two Smads to a comparable extent. Whether individual TGF- $\beta$ superfamily ligands show distinct preferences in the activation of one Smad over the other is currently unknown. We investigated the phosphorylation patterns of the two Smads in isolated islets following $30 \mathrm{~min}$ treatment with activin proteins. Stimulation with either activin A or B resulted in robust Smad2 phosphorylation in pancreatic islets (Fig. 6). Activin A induced higher levels of Smad2 phosphorylation than activin $\mathrm{B}$, which is in agreement with previous studies indicating a higher potency for this activin [33]. Unexpectedly, however, the opposite behaviour was observed for Smad3, which showed higher phosphorylation in response to activin $\mathrm{B}$ than to activin A (Fig. 6). Although beta cells are the predominant cell type in mouse pancreatic islets, other types of cells, including alpha and delta cells, are also present. To confirm whether Smad 2 and Smad 3 are also differentially phosphorylated in response to activin proteins in beta cells, we investigated Smad2 and Smad3 phosphorylation in MEPI cells, an insulin-producing cell line directly derived from cultures of E6 mouse embryos [29], and in rat insulinoma INS-1, a widely used cell model for in vitro studies of GSIS [30]. In both cell types, Smad2 was phosphorylated to a higher level in response to activin A compared with activin B, while Smad3

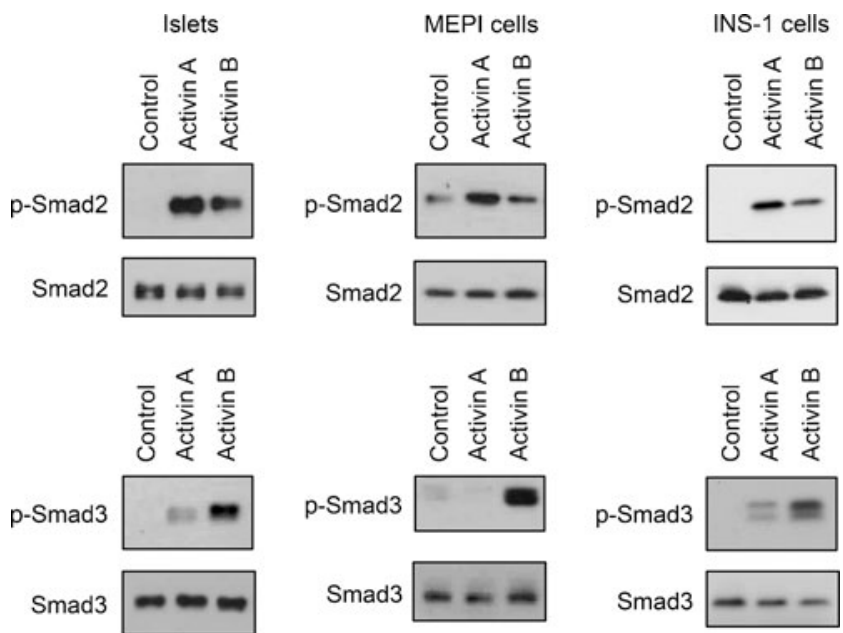

Fig. 6 Phosphorylation of Smad2 and Smad3 in islets, MEPI cells and INS-1 cells in response to 30 min treatment with activin A or activin B. Activins were used at $100 \mathrm{ng} / \mathrm{ml}$ in islets and MEPI cells and $250 \mathrm{ng} / \mathrm{ml}$ in INS-1 cells. Reprobing for total Smad2 or Smad3 proteins was performed to control for equal loading was more strongly activated in response to activin B (Fig. 6). These data demonstrate that activin proteins are able to elicit differential signalling responses in beta cells.

The differential responses of Smad proteins to the two activins prompted us to compare the ability of Smad 2 and Smad3 to stimulate glucose-mediated insulin release in pancreatic islets. Previous studies have shown that overexpression of individual Smad proteins leads to their phosphorylation and activation. Smad2 and Smad3 were overexpressed in wildtype mouse islets using recombinant adenoviruses (Fig. 7a). This resulted in comparable levels of Smad phosphorylation in the islets (Fig. 7a). Adenoviral infection was performed $36 \mathrm{~h}$ prior to assessment of GSIS, and the responses were normalised to those obtained in islets infected with a control lac $Z$ adenovirus overexpressing $\beta$-galactosidase. Adenovirus infection per se had no significant impact on GSIS by pancreatic islets (Fig. 7b, no virus). Overexpression of Smad2 increased GSIS in islets, but the increase was modest and did not reach statistical significance (Fig. 7b). In contrast, overexpression of Smad3 significantly reduced insulin secretion under the same conditions (Fig. 7b), demonstrating clear functional differences between the two Smad proteins. The ability of activin $B$ to preferentially activate $\operatorname{Smad} 3$ is in agreement with the ability of these two proteins to function as negative regulators of insulin secretion.

\section{Discussion}

We report that activin B can function as an endogenous suppressor of GSIS from pancreatic islets. We have found that a

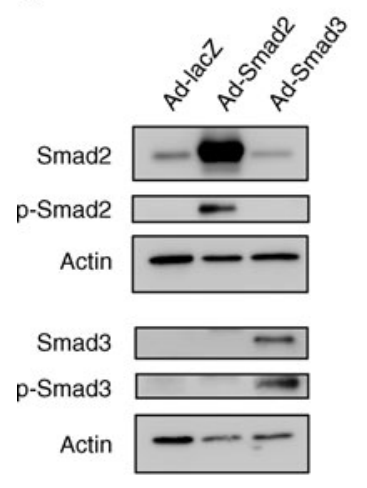

b

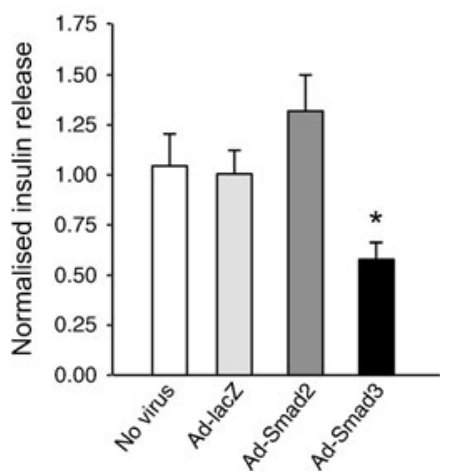

Fig. 7 (a) Overexpression of Smad2 and Smad3 in adenovirus-infected (Ad-Smad2 and Ad-Smad3) pancreatic islets. LacZ adenovirus (Ad-lacZ) was used as a control. Reprobing for beta actin was used as a loading control. (b) GSIS in batch incubation experiments with wild-type islets infected with adenoviruses expressing lacZ (Ad-lacZ), Smad2 (AdSmad2) and Smad3 (Ad-Smad3). Uninfected islets were also used as controls (no virus). Data indicate the responses of islets to $11 \mathrm{mmol} / \mathrm{l}$ glucose after normalisation to insulin levels in lacZ-infected islets (means $\pm \mathrm{SD} ; n=6$ islet samples). ${ }^{*} p<0.05$ 
activin A has the opposite activity, representing a previously unappreciated functional discrepancy between these two ligands. These differential functions correlate with a differential selectivity for activating Smad2 and Smad3 in pancreatic islets and beta cells, and with the differential ability of the two Smads to regulate GSIS in pancreatic islets. To the best of our knowledge, this is the first instance of closely related members of the TGF- $\beta$ superfamily being found to elicit differential activation of Smad proteins, and suggests that type I receptors have sophisticated signal decoding capabilities that help to preserve the specificity of ligand-encoded information. The predominant abundance of mRNA encoding the activin $B$ subunit over that of activin A indicates that islet insulin secretion may normally be under tonic suppression by endogenous activin B signalling, a concept that could be exploited to develop next-generation therapeutics for diabetes and metabolic disease. In agreement with this, acute treatment with the small-molecule inhibitor SB-431542 potentiated GSIS in wild-type mouse islets. The importance of activin signalling for glucose homeostasis in humans is underscored by recent studies indicating a positive relationship between plasma levels of activins and clinical characteristics of human type 2 diabetes [34], as well as a significant association between single-nucleotide polymorphisms in the ACVRIC gene, encoding the activin $\mathrm{B}$ receptor ALK7, and the incidence of this disease in humans [35].

We note that, as in our previous ALK7 study [17], the $\operatorname{Inh} \beta B^{-/-}$mice used here were back-crossed to a $\mathrm{C} 57 / \mathrm{Bl6}$ background. On the other hand, a recent study performed with outbred $\operatorname{Inh} \beta B^{-/-}$mice of mixed background failed to find differences in fasting insulin levels or glucose tolerance compared with wild-type controls [15]. Interestingly, $\operatorname{Inh} \beta B^{-/-}$ mice have been shown to display some defects (e.g. failure of eyelid fusion) in the C57/B16 background but not in Sv129 or hybrid backgrounds [23], suggesting that the genetic background can influence the effects of this mutation. C57/B16 is a widely used strain in metabolic studies. These mice are prone to insulin resistance and obesity, and are known to differ from other mouse strains in their insulin and glucose responses [36]. Hence, it is possible that this strain offers a more sensitive background on which to assess the effects of genetic mutations affecting molecular components that regulate insulin and glucose homeostasis.

Previous studies on the effects of activin A on insulin secretion by islet beta cells have reported somewhat conflicting results. Earlier studies indicated that activin A enhances insulin secretion [12, 13, 37]. However, more recent work reported that activin A has either no effect [4] or in fact decreases $[15,16]$ GSIS by islets. One difference between the older studies and the new work is the onset and duration of activin stimulation. While the earlier work initiated activin A treatment at the same time as glucose stimulation, the later work preincubated islets in activin $\mathrm{A}$ for several hours prior to glucose treatment and prolonged the stimulation for an additional $2 \mathrm{~h}[4,15]$ to 3 days [16]. In line with the earlier work, we have treated islets with activins acutely and concomitantly with glucose stimulation. It is possible that the effects of activins on islet GSIS fade over the course of a few hours, thus explaining how later studies may have missed these activities. This would be in agreement with a rapid, nontranscriptional effect of activin signalling in islet cells, as discussed below.

In line with our observation that Smad3 overexpression suppresses GSIS, a previous study reported that pancreatic islets isolated from Smad3 knockout mice showed enhanced insulin secretion in response to glucose as well as altered expression of several genes involved in beta cell function [38]. On the other hand, overexpression in adult islets of Smad7, which inhibits Smad signalling by all TGF- $\beta$ superfamily proteins, has been shown to reduce GSIS by affecting islet insulin content and the expression of several key genes for beta cell function, such as Mafa and Menin (also known as Men 1) [39]. These effects may have been due to the ability of Smad7 to interrupt bone morphogenetic protein signalling, which is known to be required for the maintenance of the beta cell phenotype [40]. However, we note that some of the effects that we have observed in response to activins are difficult to reconcile with the typical time course of a transcriptional response. It is unclear how Smad proteins may affect acute GSIS responses in islets and it is possible that Smad-independent mechanisms are also at play. Smad proteins are also thought to have transcription-independent functions. For example, Smad3, but not Smad2, has been found to specifically interact with and activate protein kinase A in response to TGF- $\beta$ but independently of cAMP [41]. The ability of activin ligands to regulate glucose-dependent ATP production in islets, together with the normal response to $\mathrm{KCl}$-mediated depolarisation of $\operatorname{Inh} \beta B^{-/}$islets, suggests that activin signalling may impact mitochondrial function in the beta cell. In addition, our observation that $\operatorname{Inh} \beta B^{-/-}$beta cells contain more mitochondria then their wild-type counterparts suggests roles for activin B signalling in mitochondrial biogenesis or maintenance.

In summary, our results indicate that activin A and B elicit unexpected differential signalling responses and biological activities in pancreatic islets that contribute to the regulation of glucose and insulin homeostasis in the adult organism. Understanding how activin signalling connects to mitochondrial function and insulin secretion in pancreatic islets will reveal novel insights into TGF- $\beta$ superfamily signalling and open new opportunities for therapeutic intervention in metabolic diseases.

Acknowledgements We thank G. Li (National University of Singapore, Singapore, Republic of Singapore) for providing MEPI cells, C. Wollheim (Centre Médical Universitaire, Geneva, Switzerland) for providing INS-1 cells and R. Kumar (Acceleron Pharma, Cambridge, MA, USA) for providing RAP-435 protein. 
Funding This work was supported by grants from the European Research Council, Swedish Research Council, Strategic Research Programme in Diabetes of Karolinska Institutet and Swedish Cancer Society (to CFI), and Berth von Kantzow's Foundation, Family ErlingPersson Foundation, Knut and Alice Wallenberg Foundation, Novo Nordisk Foundation, Skandia Insurance Company, Stichting af Jochnick Foundation, Strategic Research Program in Diabetes at the Karolinska Institutet, Swedish Diabetes Association, Swedish Research Council, Torsten and Ragnar Söderberg Foundation, Consortium of In Vivo Imaging of Beta-cell Receptors by Applied Nano Technology (Grant FP7-228933-2) and Diabetes Wellness Foundation (to POB).

Duality of interest The authors declare that there is no duality of interest associated with this manuscript.

Contribution statement HW, KM, PM, TG, AM and SNY designed experiments, acquired, analysed and interpreted data, and contributed to the draft of the manuscript. POB conceived and designed experiments and provided critical revisions to the final version of the manuscript. CFI conceived and designed experiments, interpreted data and wrote the manuscript. All authors approved the final version of the manuscript.

\section{References}

1. Shi Y, Massagué J (2003) Mechanisms of TGF-beta signalling from cell membrane to the nucleus. Cell 113:685-700

2. ten Dijke P, Hill CS (2004) New insights into TGF-beta-Smad signalling. Trends Biochem Sci 29:265-273

3. Moustakas A, Heldin C-H (2005) Non-Smad TGF-beta signals. J Cell Sci 118:3573-3584

4. Brown ML, Kimura F, Bonomi LM, Ungerleider NA, Schneyer AL (2011) Differential synthesis and action of TGFß superfamily ligands in mouse and rat islets. Islets 3:367-375

5. Sekine N, Yamashita N, Kojima I, Miyazaki J, Ogata E (1994) Bimodal effect of transforming growth factor-beta on insulin secretion in MIN6 cells. Diabetes Res Clin Pract 26:7-14

6. Totsuka Y, Tabuchi M, Kojima I, Eto Y, Shibai H, Ogata E (1989) Stimulation of insulin secretion by transforming growth factor-beta. Biochem Biophys Res Commun 158:1060-1065

7. Maldonado T, Kadison A, Crisera C et al (2000) Ontogeny of activin $\mathrm{B}$ and follistatin in developing embryonic mouse pancreas: implications for lineage selection. J Gastrointest Surg 4:269-275

8. Ide M, Shintani Y, Kosaka M, Sano T, Saito S (1996) Localization of activin $\mathrm{A} / \mathrm{EDF}$ in the normal and diabetic rat pancreas: immunohistochemical and in situ hybridization studies. Endocr Pathol 7:229236

9. Furukawa M, Eto Y, Kojima I (1995) Expression of immunoreactive activin $\mathrm{A}$ in fetal rat pancreas. Endocr J 42:63-68

10. Yasuda H, Inoue K, Shibata H et al (1993) Existence of activin-A in A- and D-cells of rat pancreatic islet. Endocrinology 133:624-630

11. Ogawa K, Abe K, Kurosawa $\mathrm{N}$ et al (1993) Expression of alpha, beta $\mathrm{A}$ and beta $\mathrm{B}$ subunits of inhibin or activin and follistatin in rat pancreatic islets. FEBS Lett 319:217-220

12. Florio P, Luisi S, Marchetti P et al (2000) Activin A stimulates insulin secretion in cultured human pancreatic islets. J Endocrinol Invest 23: 231-234

13. Totsuka Y, Tabuchi M, Kojima I, Shibai H, Ogata E (1988) A novel action of activin A: stimulation of insulin-secretion in rat pancreaticislets. Biochem Biophys Res Commun 156:1060-1065

14. Shibata H, Yasuda H, Sekine N, Mine T, Totsuka Y, Kojima I (1993) Activin A increases intracellular free calcium concentrations in rat pancreatic islets. FEBS Lett 329:194-198
15. Bonomi L, Brown M, Ungerleider N, Muse M, Matzuk MM, Schneyer A (2012) Activin B regulates islet composition and islet mass but not whole body glucose homeostasis or insulin sensitivity. Am J Physiol Endocrinol Metab 303:E587-E596

16. Szabat M, Johnson JD, Piret JM (2010) Reciprocal modulation of adult beta cell maturity by activin A and follistatin. Diabetologia 53: 1680-1689

17. Bertolino P, Holmberg R, Reissmann E, Andersson O, Berggren PO, Ibáñez CF (2008) Activin B receptor ALK7 is a negative regulator of pancreatic beta-cell function. Proc Natl Acad Sci U S A 105:72467251

18. Rydén M, Imamura T, Jörnvall H et al (1996) A novel type I receptor serine-threonine kinase predominantly expressed in the adult central nervous system. J Biol Chem 271:30603-30609

19. Tsuchida K, Nakatani M, Yamakawa N, Hashimoto O, Hasegawa Y, Sugino H (2004) Activin isoforms signal through type I receptor serine/threonine kinase ALK7. Mol Cell Endocrinol 220:59-65

20. Reissmann E, Jörnvall H, Blokzijl A et al (2001) The orphan receptor ALK7 and the Activin receptor ALK4 mediate signalling by Nodal proteins during vertebrate development. Genes Dev 15:2010-2022

21. Andersson O, Bertolino P, Ibanez CF (2007) Distinct and cooperative roles of mammalian Vg1 homologs GDF1 and GDF3 during early embryonic development. Dev Biol 311:500-511

22. Andersson O, Korach-Andre M, Reissmann E, Ibáñez CF, Bertolino P (2008) Growth/differentiation factor 3 signals through ALK7 and regulates accumulation of adipose tissue and diet-induced obesity. Proc Natl Acad Sci U S A 105:7252-7256

23. Vassalli A, Matzuk MM, Gardner HA, Lee KF, Jaenisch R (1994) Activin/inhibin beta B subunit gene disruption leads to defects in eyelid development and female reproduction. Genes Dev 8:414-427

24. Li DS, Yuan YH, Tu HJ, Liang QL, Dai LJ (2009) A protocol for islet isolation from mouse pancreas. Nat Protoc 4:1649-1652

25. Inman GJ, Nicolás FJ, Callahan JF et al (2002) SB-431542 is a potent and specific inhibitor of transforming growth factor-beta superfamily type I activin receptor-like kinase (ALK) receptors ALK4, ALK5, and ALK7. Mol Pharmacol 62:65-74

26. Refai E, Dekki N, Yang SN et al (2005) Transthyretin constitutes a functional component in pancreatic beta-cell stimulus-secretion coupling. Proc Natl Acad Sci U S A 102:17020-17025

27. Fujii M, Takeda K, Imamura T et al (1999) Roles of bone morphogenetic protein type I receptors and smad proteins in osteoblast and chondroblast differentiation. Mol Biol Cell 10:3801-3813

28. Miyake S, Makimura M, Kanegae Y et al (1996) Efficient generation of recombinant adenoviruses using adenovirus DNA-terminal protein complex and a cosmid bearing the full-length virus genome. Proc Natl Acad Sci U S A 93:1320-1324

29. Li G, Luo R, Zhang J et al (2009) Derivation of functional insulinproducing cell lines from primary mouse embryo culture. Stem Cell Res 2:29-40

30. Asfari M, Janjic D, Meda P, Li G, Halban PA, Wollheim CB (1992) Establishment of 2-mercaptoethanol-dependent differentiated insulin-secreting cell lines. Endocrinology 130:167-178

31. Koncarevic A, Kajimura S, Cornwall-Brady M et al (2012) A novel therapeutic approach to treating obesity through modulation of TGF $\beta$ signaling. Endocrinology 153:3133-3146

32. Brown CW, Houston-Hawkins DE, Woodruff TK, Matzuk MM (2000) Insertion of Inhbb into the InHbA locus rescues the InHbAnull phenotype and reveals new activin functions. Nat Genet 25:453457

33. Brown CW, Li L, Houston-Hawkins DE, Matzuk MM (2003) Activins are critical modulators of growth and survival. Mol Endocrinol 17:2404-2417

34. Wu H, Wu M, Chen Y, Allan CA, Phillips DJ, Hedger MP (2012) Correlation between blood activin levels and clinical parameters of type 2 diabetes. Exp Diabetes Res 2012:410579 
35. Taneera J, Lang S, Sharma A et al (2012) A systems genetics approach identifies genes and pathways for type 2 diabetes in human islets. Cell Metab 16:122-134

36. Berglund ED, Li CY, Poffenberger G et al (2008) Glucose metabolism in vivo in four commonly used inbred mouse strains. Diabetes 57:1790-1799

37. Furukawa M, Nobusawa R, Shibata H, Eto Y, Kojima I (1995) Initiation of insulin secretion in glucose-free medium by activin $\mathrm{A}$. Mol Cell Endocrinol 113:83-87

38. Lin HM, Lee JH, Yadav $\mathrm{H}$ et al (2009) Transforming growth factor-beta/Smad3 signaling regulates insulin gene transcription and pancreatic islet beta-cell function. J Biol Chem 284:1224612257

39. Smart NG, Apelqvist AA, Gu X et al (2006) Conditional expression of Smad7 in pancreatic beta cells disrupts TGF-beta signaling and induces reversible diabetes mellitus. PLoS Biol 4:e39

40. Goulley J, Dahl U, Baeza N, Mishina Y, Edlund H (2007) BMP4BMPR1A signaling in beta cells is required for and augments glucose-stimulated insulin secretion. Cell Metab 5:207-219

41. Zhang L, Duan CJ, Binkley C et al (2004) A transforming growth factor beta-induced $\mathrm{Smad} 3 / \mathrm{Smad} 4$ complex directly activates protein kinase A. Mol Cell Biol 24:2169-2180 